\title{
Consumers' Purchase Intentions For Foreign Products: An Empirical Research Study In Istanbul, Turkey
}

Elif Akagun Ergin, Cankaya University, Turkey

Handan Ozdemir Akbay, Cankaya University, Turkey

\begin{abstract}
Consumers in developing countries seem to possess an increasing demand for the purchase of foreign products. Turkey is a magnet for multinational corporations that view the country as a must-win market. It has become important to determine the underlying intentions that drive the purchase decisions for foreign products in the Turkish market. The purpose of this study is to contribute to the literature by examining the purchase intentions of urban, Turkish consumers for foreign products in three specific categories (apparel, chocolate and personal care products). These categories were selected by taking their applicability to urban consumers into consideration. A field study was carried out at three major shopping malls in Istanbul, with the participation of 600 urban, Turkish consumers. Surveys, consisting of 3 parts and a total of 50 questions, have been used to gather data. In the first part, the subjects were asked about the factors that affect their purchasing motives. The top five factors were reported as perceived brand prestige, quality, value, purchase intention, and influence of others. In the second part, questions were asked regarding the subject's reactions about foreign brands according to the determined categories. Finally in the third part, the participants were asked about their demographics and other personal factors. The empirical evidence provides insights into the significance of impact of product category, perceived brand prestige, perceived brand quality and influence of others. The results of the multi-linear regression analysis are reported along with significant implications for marketing managers.
\end{abstract}

Keywords: consumer perceptions, brand quality, brand value, brand prestige, foreign products.

\section{INTRODUCTION}

$\mathrm{n}$ the recent years, competition among brands has become more complicated as the number of foreign brands increase. As a result, many foreign brands compete with older local brands, and this is more prevalent in developing markets such as Turkey. Consumers in developing markets possess various intentions for purchasing foreign products. Research into the underlying psychological reasons that drive their purchase decisions is of significant importance, as this can help marketers understand why consumers in developing countries choose to purchase foreign products. Additional insight into consumers' purchasing intentions can help support and enhance the strategic positioning of the foreign products. Although research on foreign brands have been widely noted in the literature (Bearden and Etzel 1982; Yip 1995), there is still a lack of research on consumers' purchasing motives for foreign brands across different product categories as well as various individual difference variables (Steenkamp, Batra, and Alden 2002).

To contribute to the relevant literature, this study examines consumers'purchasing intentions for three categories of foreign products. These categories include apparel, chocolate and personal care products. 


\section{Research Hypotheses}

A primary factor believed to have an influence over the purchase intention for foreign products is perceived quality. The construct of perceived quality is defined as a consumer's evaluation of a brand's overall excellence based on intrinsic (e.g., performance, durability) and extrinsic cues (e.g., brand name, service) (Kirmani and Baumgartner 2000). These assessments of quality are similar to attitudinal judgments, and consumers depend on how effectively a specific brand satisfies internal quality standards in their assessment of a brand's overall excellence with regards to their consumption experience. Specifically, these internal reference points may include stored evaluative information about the target brand or cognitive comparison standards that can be used to evaluate individual attributes (Kirmani and Baumgartner 2000).

In most cases, brand name is perceived as a key indicator of quality (Rao and Monroe, 1989), and foreign brands generally help enhance a brand's perceived quality. Consumers rely on various quality cues to evaluate their perceptions of foreign brand quality. Consumers' perceived quality of a brand is considered more rewarding when its consumption is largely inconspicuous and of relatively low social display value. To reinforce this view, Kirmani and Baumgartner (2000) suggest that consumers rely more on internal standards to evaluate a brand's quality. Consumers who experience a high level of perceived quality are more likely to exhibit positive behavioral intentions such as positive word-of-mouth and repurchase intentions towards the brand. This will ulitmately have a greater effect if the product has a relatively low social display value, and is purchased and consumed in private.

Even though the concept of prestige may mean different things to different consumers, the general assumption is that prestige brands are infrequently purchased, require a higher level of interest and strongly relate to an individual's self-concept. A consumer's perceived prestige towards a brand is created from a multitude of interactions between the consumer and various factors within the environment, hence it is expected that consumers would have different perceptions of prestige levels for the same brands. Consumers develop prestige meanings for brands based upon interactions with people (e.g., aspired and/or peer reference group), object properties (e.g., best features), and hedonic values (e.g., sensory beauty) (Vigneron and Johnson 1999).

In general, foreign brands have higher prestige because of their relative scarcity and higher price compared with local brands (Batra et al. 2000). Along the same lines, Kapferer (1997) suggests that consumers may prefer foreign brands because of associations of higher prestige. In addition, certain consumers prefer to buy foreign brands as it enhances their self-image as being cosmopolitan, sophisticated, and modern (Friedman 1990). Therefore, perceived prestige associated with foreign brands provides intangible value to consumers, and consumers tend to reciprocate this value by enhancing their brand loyalty as well as transferring its good image to others through positive word-of-mouth.

Hence, higher perceived prestige of foreign products may display wealth and power,and one could consider that highly visible products would dominate the conspicuous segment of consumers. Perceived value is another important factor that helps explain repeat purchase behavior and brand loyalty (Parasuraman and Grewal 2000). Encompassing four diverse meanings, Zeithalm (1988) defines perceived value as "the consumer's overall assessment of the utility of a product based on perceptions of what is received and what is given". A majority of consumers feel that value is what the consumer gets for what they give, an external orientation is present.

Most of the previous studies on the construct of perceived value have centered on this orientation (Bojanic 1996; Zeithaml 1985), and this definition of value is adopted in this study. For a typical consumer, value associates the idea of a comparative assessment of the benefit and sacrifice combinations of different brands. Subsequently, consumers are more likely to rely on external or extrinsic information to evaluate a brand's value (Kirmani and Baumgartner 2000).

Previous research revealed that a perceived limited supply of products enhances a consumer's perceived value and preference for a brand (Pantzalis 1995; Verhallen 1982). To reinforce this view, Solomon (1994) posits that items that are in limited supply have high value, while those readily available are less desirable. Indeed, consumers generally perceive products with a high level of value as limited and rare items, and scarcity of such products has a greater effect on demand if the product can be purchased and consumed in public contexts. 
In a typical collective society like Turkey, it is of major significance to note a fourth factor in foreign product purchases, the influence of others. This influence is the change in behavior that one person causes in another, intentionally or unintentionally, as a result of the way the changed person perceives themselves in relationship to the influencer, other people and society in general. As Gladwell (2000) describes new products or fashions are introduced by innovators, who tend to be creative and nonconforming. Then early adopters join in, followed by the early majority. By this time, a substantial number of people are using the idea or product, and normative and informational influence encourages others to conform as well. The early majority is followed by a second group that Gladwell calls the late majority, and then finally by the laggards, who tend to be highly conventional and resistant to change. This particular construct shall not be overlooked in an effort to explain turkish consumers' purchase intentions for foreign products.

Given the preceding discussions about these constructs, we hypothesize the following:

H1: Perceived quality, prestige, value and influence of others have a great influence on consumers' purchase intentions for foreign apparel brands.

H2: Perceived quality, prestige, value and influence of others have a great influence on consumers' purchase intentions for foreign personal care brands.

H3: Perceived quality, prestige, value and influence of others have a great influence on consumers' purchase intentions for foreign chocolate brands.

\section{METHODOLOGY}

This study employed a sample of 600 urban Turkish consumers. Urban consumers were selected because; they represented the required characteristics needed for this study (access to foreign brands on a wide basis). Consumers between the ages of 15-60 have been selected for this research. A mall-intercept approach was adopted in the data collection. The study was carried out at three major shopping malls at different locations in Istanbul.

A structured survey method has been used to collect primary information for this study. Surveys were prepared after a thorough literature review and they consisted of two parts. In the first part, the subjects were asked about the factors that effect their purchase intentions and their reactions about foreign brands according to the determined categories. When factor analysis was run, four factors turned up (F1: perceived prestige, F2: perceived quality, F3: perceived value and F4: influence of others as independent variables). In the second part, the participants were asked about their demographics and other personal factors. Before carrying out the fieldwork survey, a pilot test was conducted with 40 subjects in Istanbul in order to pretest the format and suitability of questions as set out in the survey.

Product categories were selected by taking their applicability to urban consumers into consideration. Using these criteria, three different product categories were selected (apparel, personal care products and chocolate) to measure the consumer's purchase intentions for foreign brands. The brands within each product category were selected by visiting three shopping malls in Istanbul and recording all the available brand names within the stores and supermarkets inside these malls. This was how we managed to develop a final list of brand names within the product categories of interest.. A total of 104 brands (15 brands for chocolate, 58 brands for apparel and 31 brands for personal care products) were compiled. Some of these brands include Mango, Nike, Adidas, Benetton, Levi's, Zara, Benetton, Nautica, Gap, Burberry, Tommy Hilfiger., Nestle, Cadbury, Toblerone, Hershey's, Magnum, Lindt, Milka., Vichy, Clarins, Nivea, Clinique, Diadermine, Loreal, Maybelline, Lancome, Estee Lauder, Roc.. etc.

Following the return of completed surveys, the data was coded and entered into the computer. The coded data was sorted and analyzed by SPSS 16.0 program. To determine the independent variables (factors effecting purchase intentions) of the study, Factor analysis was used and the hypotheses of the study were tested by MultiLinear Regression Analysis method. 


\section{RESULTS}

The majority of the subjects that participated in the research study are in the 25-29 age group. Analysis (as depicted in Table 1) reveal that $\% 56,4$ of the subjects are female and $\% 43,6$ of the subjects are male consumers. The monthly average income of households has been divided into six categories and subjects were asked to choose the category that fits them. The majority of the subjects $(\% 38,9)$ stated that they have an average monthly income of $2500 \mathrm{TL}$ and over.

Table 1. Demographic Profile

\begin{tabular}{|c|c|c|c|}
\hline Age & Frequency & Gender & Frequency \\
\hline $15-19$ & 10,1 & Female & 56,4 \\
$20-24$ & 19,7 & Male & 43,6 \\
$25-29$ & 25,8 & Income Level & 7,4 \\
$30-34$ & 8,3 & $500-999 \mathrm{TL}$ & 14,8 \\
$40-44$ & 14,3 & $1000-1499 \mathrm{TL}$ & 21,3 \\
$45-49$ & 11 & $1500-1999 \mathrm{TL}$ & 17,6 \\
$50-54$ & 6,7 & $2000-2499$ & 38,9 \\
$55-59$ & 4,1 & 2500 and over & \\
\cline { 2 - 3 } & & & \\
\hline
\end{tabular}

Table 2. Most Preferred Foreign Brands (Top 10)

\begin{tabular}{|c|c|c|c|c|c|}
\hline \multicolumn{2}{|c|}{ Chocolate Category } & \multicolumn{2}{|c|}{ Personal Care Category } & \multicolumn{2}{|c|}{ Apparel Category } \\
\hline Brand Name & $\%$ & Brand Name & $\%$ & Brand Name & $\%$ \\
\hline Nestle & 18,3 & Clinique & 26,2 & Mango & 21,2 \\
\hline Milka & 15,8 & Lancome & 14,3 & Levi's & 15,8 \\
\hline Magnum & 11,8 & L'oreal & 10,5 & Guess & 13,0 \\
\hline Lindt & 10,3 & Estee Lauder & 9,5 & Zara & 12,5 \\
\hline Ferrero & 9,5 & Dermalogica & 8,0 & DKNY & 9,2 \\
\hline Toblerone & 8,0 & Vichy & 7,8 & Nike & 7,2 \\
\hline Ritter Sport & 7,7 & Garnier & 7,0 & Diesel & 5,7 \\
\hline Merci & 7,5 & Clarins & 6,5 & Gap & 5,3 \\
\hline Guylian & 7,1 & Lierac & 6,4 & U.S Polo & 5,2 \\
\hline Cadbury & 4,0 & Johnson's & 3,8 & Timberland & 4,9 \\
\hline
\end{tabular}

Table 2 presents ten of the most preferred foreign brands in each of the product categories. The participants listed Nestle, Milka and Magnum as their top three highly preferred "chocolate" brands. For apparel brands, Mango, Levi's and Guess took the top three spot. Clinique, Lancome and Loreal brands were reported as turkish consumers' favorite brands among personal care products.

The reliability of the scale was tested, Cronbach Alpha coefficent was measured as 0,897. This proved the scale to be highly reliable. A principal component factor analysis with Varimax rotations was then used to explore the set of variables in consumer purchase intentions for foreing products. The factor analysis resulted in four factors, with twenty-five items categorized under these factors. Prior to the factor analysis, Kaiser-Meyer-Olkin test was done to assess the validity of the sample size. The KMO value was determined to be 0,896 . It was concluded that the KMO value was a sufficent value to perform the factor analysis. The results of the Bartlett test revealed an existing relationship among the variables. (Chi square: 1,9183; sig: 0,000). Thus, it was concluded that a factor analysis was applicable. The factor analysis resulted in four factors, accounting for \%57,562 of the total variance. (Table 3) 
Table 3. Factor Loadings

\begin{tabular}{|c|c|c|}
\hline & Factor Loads & $\%$ of Variance \\
\hline $\begin{array}{l}\text { Factor 1: Perceived Quality } \\
\text { - The quality of the product is important for me. } \\
\text { - The quality of the product increases the value of the brand in my perception. } \\
\text { - The quality of the product has an effect on my positive attitude toward the brand. } \\
\text { - The brand of a product is a sign of its quality. } \\
\text { - I believe that foreign brands have higher quality than national /local brands. } \\
\text { - } \quad \text { Foreign brands are more enduring/long-lasting than national /local brands. }\end{array}$ & $\begin{array}{l}, 798 \\
, 721 \\
, 631 \\
, 559 \\
, 400 \\
, 356\end{array}$ & 18,177 \\
\hline $\begin{array}{l}\text { Factor 2: Perceived Prestige } \\
\text { - Having foreign brands provide status/prestige to individuals in the society. } \\
\text { - Having foreign brands is a sign of prosperity. } \\
\text { - Having foreign brands increases my respectability. } \\
\text { - } \quad \text { It is important to me that the brands I own/use provide prestige/status/respect to me } \\
\text { by members of society. }\end{array}$ & $\begin{array}{l}, 742 \\
, 685 \\
, 631 \\
, 677 \\
, 367\end{array}$ & 15,807 \\
\hline $\begin{array}{l}\text { Factor 3: Influence of Others } \\
\text { - I care deeply about what my family and friends think about the foreign brands I } \\
\text { purchase. } \\
\text { - The advice of someone who is a regular user of a particular brand is a major reason } \\
\text { I buy the same brand. } \\
\text { - My social environment has a great impact on my brand selections. } \\
\text { - People around me encourage me to purchase foreign brands. }\end{array}$ & $\begin{array}{l}, 670 \\
, 570 \\
, 743 \\
, 496\end{array}$ & 13,810 \\
\hline $\begin{array}{l}\text { Factor 4: Perceived Value } \\
\text { - I always get my money's worth from the foreign brands I purchase. } \\
\text { - It makes me happy to own foreign brands that most people can not have. } \\
\text { - The more a brand is preferred, the higher its value. }\end{array}$ & $\begin{array}{l}, 725 \\
, 716 \\
, 426 \\
\end{array}$ & 9,598 \\
\hline
\end{tabular}

To test the hypotheses of the study, the four independent variables (perceived prestige,quality, value and influence of others) and the dependent variable (purchase intention for the brand) were entered simultaneously into a multiple regression analysis. We ran the regression model separately for each product category (chocolate, personal care and apparel).

Table 4. Multi Linear Regression Results For Foreign Apparel Brands Category

\begin{tabular}{|c|c|c|c|c|c|}
\hline \multirow[b]{2}{*}{ Model } & \multicolumn{2}{|c|}{ Unstandardized Coefficients } & \multirow{2}{*}{$\begin{array}{c}\begin{array}{c}\text { Standardized } \\
\text { Coefficients }\end{array} \\
\text { Beta }\end{array}$} & \multirow[b]{2}{*}{$\mathbf{t}$} & \multirow[b]{2}{*}{ Sig. } \\
\hline & B & Std. Error & & & \\
\hline 1 (Constant) & ,191 & ,084 & & 2,276 & ,024 \\
\hline Perceived Value &, 102 & ,025 &, 137 & 4,098 &, 000 \\
\hline Perceived Quality &, 284 &, 025 & 351 & 11,460 &, 000 \\
\hline Perceived Prestige & ,326 & ,026 & 391 & 12,326 &, 000 \\
\hline Influence of Others & , 190 & ,026 & ,250 & 7,240 &, 000 \\
\hline
\end{tabular}

$\mathbf{R}=\mathbf{0 , 9 0} \quad \mathbf{R}^{2}=\mathbf{0 , 8 2} \quad \mathrm{F}=\mathbf{3 7 6 , 5 7 0} \quad \mathrm{p}=\mathbf{0 , 0 0 0}$

Dept. variable: Purchase intention

The testing of the $\mathrm{H} 1$ hypothesis (Table 4) reveal that there is a significant relationship among these factors and their influence on purchase intention $\left(R=0,90 R^{2}=0,82 F=376,570 ; p<0,00\right)$. These four independent variables (perceived quality, prestige, value and influence of others) together are able to explain $82 \%$ of the overall variation in purchase intentions for foreign apparel brands category. This finding would indicate that perceived quality, 
prestige, value and influence of others variables do indeed have an influence on consumers' purchase intention for foreign apparel brands. However, there may also be other effective factors that may explain a substantial amount of the overall variation. According to $\beta$ coefficient, the four independent variables with an influence on consumers' purchase intentions can be rank ordered as perceived prestige $(0,391)$ perceived quality $(0,351)$, influence of others $(0,250)$ and perceived value $(0,137)$. Based on the overall analysis, $\mathrm{H} 1$ is accepted (sig. $=0,000<0.05)$.

H2 hypothesis had to do with determining whether perceived quality, prestige, value and influence of others factors had any influence on consumers' purchase intentions for foreign personal care products. Table 5 shows the results of the multi-linear regression analysis on this hypothesis. Based on the analysis, there is a significant relationship between these four factors and their influence on purchase intention $\left(R=0,93 ; R^{2}=0,87 ; F=\right.$ $581,354 ; \mathrm{p}<0,00)$. Based on the $\beta$ coefficient, the four independent variables with an influence on consumers' purchase intentions can be arranged as perceived quality $(0,459)$, perceived prestige $(0,390)$, perceived value $(0,284)$ and influence of others $(0,070)$. Hence, $\mathrm{H} 2$ is also accepted (sig. $=0,000<0.05)$.

Table 5. Multi Linear Regression Results For Foreign Personal Care Brands Category

\begin{tabular}{|c|c|c|c|c|c|}
\hline \multirow{2}{*}{ Model } & \multicolumn{2}{|c|}{ Unstandardized Coefficients } & \multirow{2}{*}{$\begin{array}{c}\text { Standardized } \\
\text { Coefficients }\end{array}$} & \multirow[t]{2}{*}{$\mathbf{t}$} & \multirow[t]{2}{*}{ Sig. } \\
\hline & B & Std. Error & & & \\
\hline 1 (Constant) & ,254 & ,082 & & 3,112 &, 002 \\
\hline Perceived Value & ,230 & ,022 & ,248 & 10,488 &, 000 \\
\hline Perceived Quality & ,315 & 019 & ,459 & 16,708 &, 000 \\
\hline $\begin{array}{l}\text { Perceived Prestige } \\
\text { Influence of Others }\end{array}$ & $\begin{array}{l}, 274 \\
, 063\end{array}$ & $\begin{array}{l}, 020 \\
, 020\end{array}$ & $\begin{array}{l}, 390 \\
, 070\end{array}$ & $\begin{array}{c}13,667 \\
3,151\end{array}$ & $\begin{array}{l}, 000 \\
, 000\end{array}$ \\
\hline
\end{tabular}

Dept. variable: Purchase intention

These four independent variables together are able to explain $87 \%$ of the overall variation in purchase intentions for foreign personal care products category. Contrary to the previous hypothesis, this finding would indicate that perceived quality, prestige, value and influence of others variables do indeed have an influence on consumers' purchase intention for foreign personal care products.

Table 6. Multi Linear Regression Results For Foreign Chocolate Brands Category

\begin{tabular}{|c|c|c|c|c|c|}
\hline \multirow[b]{2}{*}{ Model } & \multicolumn{2}{|c|}{ Unstandardized Coefficients } & \multirow{2}{*}{$\begin{array}{c}\text { Standardized } \\
\text { Coefficients }\end{array}$} & \multirow[b]{2}{*}{$\mathbf{t}$} & \multirow[b]{2}{*}{ Sig. } \\
\hline & B & Std. Error & & & \\
\hline 1 (Constant) & ,383 & 075 & & 5,098 &, 000 \\
\hline Perceived Value &, 050 &, 024 & ,067 & 2,087 &, 000 \\
\hline Perceived Quality & ,391 &, 022 & ,469 & 17,482 &, 000 \\
\hline Perceived Prestige & 197 & 025 & ,260 & 7,959 &, 000 \\
\hline Influence of Others & ,257 & ,019 & ,361 & 13,700 &, 000 \\
\hline
\end{tabular}

$R=0,91 \quad R^{2}=0,84 \quad F=427,253 \quad p=0,000$

Dept. variable: Purchase intention

The testing of the H3 hypothesis (Table 6) reveal that there is a significant relationship between these factors and their influence on purchase intention $\left(R=0,91 \quad R^{2}=0,84 \quad F=427,253 ; p<0,00\right)$. These four independent variables (perceived quality, prestige, value and influence of others) together are able to explain $84 \%$ of the overall variation in purchase intentions for foreign chocolate brands category. This finding would indicate that perceived quality, prestige, value and influence of others variables do indeed have an influence on consumers' purchase intention for foreign chocolate brands. However, there may also be other The four independent variables can be 
aligned as perceived prestige $(0,260)$ perceived quality $(0,469)$, influence of others $(0,361)$ and perceived value $(0,067)$. H3 is accepted (sig. $=0,000<0.05)$.

\section{LIMITATIONS AND FUTURE RESEARCH}

Some limitations to this study should be noted, and efforts to resolve them would serve as avenues for future research in this field. First, the findings of the study may have limited generalizability. The sample, which seemed appropriate for this particular study, was urban consumers from Istanbul, the largest city in Turkey with a population over twelve milllion people. It would be more meaningful if the same findings hold consistent in different types of consumers from other urban cities across the country as well as rural Anatolian cities. Second, the factors investigated were limited to perceived brand prestige, quality, value, and influence of others. Future research needs to examine other potential factors to explain consumers' purchase intentions for foreign products.

\section{REFERENCES}

1. Batra, R., Ramaswamy, V., Alden, D. L., Steenkamp, J. and Ramachander, S. (2000), "Effects of Brand Local/Nonlocal Origin on Consumer Attitudes in Developing Countries", Journal of Consumer Psychology, Vol. 9, pp. 83-95

2. Bearden, W. O. and Etzel, M. J. (1982), "Reference Group Influence on Product and Brand Purchase Decisions", Journal of Consumer Research, Vol. 9, pp. 183-194.

3. Bojanic, D. C. (1996), "Consumer Perceptions of Price, Value and Satisfaction in the Hotel Industry: An Exploratory Study", Journal of Hospitality and Leisure Marketing, Vol. 4, No. 1, pp. 5-22.

4. Friedman, J. (1990), "Being in the World: Globalization and Localization", Theory, Culture and Society, Vol. 7, pp. 311-328.

5. Gladwell, M. (2000). The Tipping Point: How Little Things Can Make a Big Difference, first published by Little Brown. ISBN 0-316-31696-2.

6. $\quad$ Kapferer, J. N. (1997), Strategic Brand Management, 2nd ed., Dover, NH, Kogan Page.

7. Kirmani, A. and Baumgartner, H. (2000), "Reference Points Used in Quality and Value Judgements", Marketing Letters, Vol. 11, No. 4, pp. 299-310.

8. Parasuraman, A. and Grewal, D. (2000), "The Impact of Technology on the Quality-Value-Loyalty Chain: A Research Agenda", Journal of the Academy of Marketing Science, Vol. 28, No. 1, pp. 168-174.

9. Pantzalis, I. (1995), Exclusivity Strategies in Pricing and Brand Extension, Unpublished Doctoral Dissertation, AZ, University of Arizona.

10. Rao, A. R. and Monroe, K. B. (1989), "The Effect of Price, Brand Name, and Store Name on Buyers' Perceptions of Product Quality: An Integrative Review", Journal of Marketing Research, Vol. 26, pp. 351357.

11. Steenkamp, J., Batra, R., and Alden, D. L. (2002), "How Perceived Brand Globalness Creates Brand Value", Journal of International Business Studies, Vol. 34, No. 1, pp. 1-13.

12. Solomon, M. R. (1994), Consumer Behavior, 2nd ed., Boston, MA: Allyn and Bacon.

13. Verhallen, T. M. (1982), "Scarcity and Consumer Choice Behavior", Journal of Economic Psychology, Vol. 2, No. 2, pp. 299-321.

14. Vigneron, F. and Johnson, L. W. (1999), “A Review and a Conceptual Framework of Prestige-Seeking Consumer Behavior”, Academy of Marketing Science Review, Vol. 1, pp. 1-17.

15. Yip, G. S. (1995), Total Global Strategy: Managing for World-Wide Competitive Advantage, Englewood Cliffs, NJ: Prentice-Hall.

16. Zeithaml, V. A. (1988), "Consumer Perceptions of Price, Quality and Value: A Means-End Model and Synthesis of Evidence”, Journal of Marketing, Vol. 52, July, pp. 2-22. 


\section{NOTES}

